\title{
Inhibitory Effect of PG-Platycodin D on the Development of Atopic Dermatitis-Like Skin Lesions in ICR Mice
}

\author{
Sae-Jin Park', Yoon Suk Kim² and Tack-Joong Kim* \\ ${ }^{1}$ Division of Biological Science and Technology, College of Science and Technology, Yonsei University, Wonju 220-710, Korea \\ ${ }^{2}$ Department of Biomedical Laboratory Science, College of Health Sciences, Yonsei University, Wonju, 220-710, Korea
}

Received July 20, 2012 /Revised September 24, 2012 /Accepted October 22, 2012

\begin{abstract}
Atopic dermatitis is characterized by chronically pruritic and inflammatory dermatitis. In this study, we investigated the effect of Platycodon grandiflorum including platycodin D (PG-Platycodin D) in an atopic dermatitis-like mouse model. An atopic dermatitis-like skin lesion was induced by repeated treatment of 2,4-dinitrochlorobenzene (DNCB) on the dorsal skin of ICR mice. The efficacy of PG-Platycodin D was tested by observing scratching behavior, the skin severity score, and histopathologic analysis. PG-Platycodin D reduced the DNCB-induced increase in scratching behavior and the skin severity score. In addition, histopathologic analysis revealed a reduction in the thickening of the epidermis in the PG-Platycodin D group. These results may contribute to the development of a therapeutic drug for the treatment of atopic dermatitis.
\end{abstract}

Key words : Atopic dermatitis, PG-playticodin D, severity score, scratching behavior

\section{서 론}

산업화와 복잡한 사회 구조로 인한 스트레스, 식생활의 변 화, 환경오염의 증가 등은 새로운 질병을 발생시키는 원인이 된다. 이에 따라 알레르기, 고혈압, 당뇨병, 만성 스트레스 등 과 연관된 질병들이 만연하고 있다. 특히 알레르기성 질환으 로서 천식, 비염, 아토피성 피부염, 그리고 알레르기성 결막염 등이 점차 증가하고 있는 추세이다[1,8]. 특히 피부과 질환 중 에서 급격히 증가하고 있는 것은 화학물질, 약물, 기타 자극물 에 의한 알레르기성 아토피 피부염이다[11]. 알레르기성 아토 피 피부염의 치료제로서 부신피질 호르몬제나 항 히스타민제 가 사용되고 있으나 이러한 치료제의 장기간 투여는 다양한 부작용을 야기한다. 따라서 이러한 부작용을 최소화 시켜줄 수 있는 천연재료의 약용화가 필요한 실정이다[20].

알레르기성 아토피 피부염의 초기에는 병리학적으로 피부 의 장벽이 긁는 행위에 의해서 붕괴된다. 염증성 사이토카인 에 의해서 다양한 화학주성물질들이 상처부위에서 나타나고 백혈구들이 활성화된다. 알레르기성 아토피 피부염은 비정상 적인 $\mathrm{IgE}$ 의 생성, 말초 부위의 호산구 증가, 비만 세포의 활성 화 등을 특징으로 하는 알레르기 관련 $\mathrm{T}$ helper (Th) 2 연관 질환과 같은 형태에 기인한다[5,7,17,22].

2,4-Dinitrochlorobenzene (DNCB)로 유발된 알레르기성 접 촉피부염은 염증관련 물질을 분비하며, 이들 염증관련 물질은 생체대사에 영향을 미치고 과도하게 생성되었을 경우에는 조

*Corresponding author

Tel : +82-33-760-2242, Fax : +82-33-760-2183

E-mail : ktj@yonsei.ac.kr
직 손상, 지질 과산화, DNA 손상 그리고 효소 불활성화를 유 발하며 만성, 급 만성 스트레스와 충격, 염증 등의 복잡한 조건 들과 연관되어 있다[4,13].

도라지(Platycodon grandiflorum)는 초롱꽃과(Campanulacead) 에 속하는 다년생 초본류로서 중국, 일본 및 우리나라 각지에 자생하고 있으며 예로부터 약용과 식용으로 이용되어 최근까 지 널리 재배하여 생산되고 있다. 1940년도부터 현재까지 17 종의 saponin 종류가 분리되었고 그 구조도 밝혀졌다. 이외에 도 sterol, Platycodin D 등의 조성이 조사되어 있다. 기본적으 로 감기, 천식, 페결핵에 거담제로서 유용한 것으로 보고되고 있어서 기관지 천식 치료나 면역증강 및 활성에 효능이 있는 것으로 밝혀지고 있다[9-13]. 도라지에서 약효를 나타내는 주 성분들 중 Platycodin $\mathrm{D}$ 는 도라지 뿌리에 존재하는 트리터펜 사포닌계(triterpenoid saponin) 화합물 중의 하나로 항 염증 효과, 항 비만효과, 콜레스테롤 저하효과, 통각 억제효과가 있 는 것으로 보고 되었다[10,18].

본 연구실에서는 Platycodin $\mathrm{D}$ 를 포함하는 도라지 추출물 (PG-Platycodin D)에 대한 선행연구로, PG-Platycodin D가 $\mathrm{IgE} / \mathrm{Ag}$ 에 의해 매개된 아나필락틱 쇼크와 비만 세포의 탈 과 립현상을 억제하고, 비만 세포 내 IL-3 사이토카인 유전자의 발현을 저해한다는 것을 밝힌 바가 있다.

본 연구에서는 이러한 항 알러지 효과를 갖는 PGPlatycodin $\mathrm{D}$ 를 $\mathrm{DNCB}$ 로 유발된 접촉성 피부염 동물모델에 처치하여, scratching behavior, skin severity score, skin thickness에 PG-Platycodin D가 미치는 영향에 대해서 연구하였다. 


\section{재료 및 방법}

\section{실험재료}

2,4-dinitrochlorobenzene (DNCB)와 olive oil 및 acetone은 Sigma-Aldrich (St. Louis, Mo, USA)에서 구입하였다. 사용한 $\mathrm{DNCB}$ 는 Acetone과 olive oil 혼합 용액으로 $0.5 \%$ 와 $1 \%$ 의 농 도로 용해한 후 사용하였으며, $5 \%$ 의 Platycodin D를 포함하는 도라지 추출물(PG-Platycodin D)은 표준화되어 (주)비엔씨바 이오팜으로부터 제공받아 실험에 사용하였다.

\section{실험동물의 사육}

실험동물은 male ICR mice 6주령을 Orient Bio (Gangneung, Korea)로부터 구매하여 온도 $20-22^{\circ} \mathrm{C}$ 와 습도 40-50\%의 환경에서 사육하였다. 모든 동물들은 표준화 된 사료 와 물을 제공하였으며, 연세대학교의 Institutional Animal Care and Use Committee (IACUC) (Wonju, Korea)가 본 연구의 동물 실험을 승인하였다. 실험군은 2,4-dinitrochlorobenzene (DNCB) 를 도포하지 않은 정상 대조군(Normal군), DNCB 단독 도포군 (DNCB군), $\mathrm{DNCB}$ 와 $10 \mathrm{mg} / \mathrm{ml}$ 의 5\% PG-Platycodin D를 도 포한 군(PD $5 \%+\mathrm{DNCB}$ 군)으로 나누었다. 각 군에 6 마리씩 분 리하여 polycarbonate cage에 수용하고, 고형사료와 물을 자 유롭게 섭취시키면서 1 주 동안 적응시킨 후 사용하였다.

\section{접촉성 피부염의 유도 및 시료처리}

접촉성 피부염을 유발하기 위해 acetone과 olive oil을 3:1 로 섞어 만든 기제에 2,4-dinitrochlorobenzene (DNCB)를 녹 여서 만든 $1 \% \mathrm{DNCB}$ 용액과 $0.5 \% \mathrm{DNCB}$ 용액을 사용하였 다. ICR mice의 등쪽 부위를 제모하고 하루 동안 피부를 진 정시킨 뒤, $1 \% \mathrm{DNCB}$ 용액을 등쪽 부위에 도포하여 sensitization한다. 4 일 후부터 2 주 동안 $0.5 \% \mathrm{DNCB}$ 용액을 반복적 으로 도포하여 접촉성 피부염을 유발하였다(Fig. 1). $1 \%$ $\mathrm{DNCB}$ 용액 도포 후에 PD $5 \%+\mathrm{DNCB}$ 군의 경우에는 D.W에 $5 \%$ PG-Platycodin D 추출물을 녹여서 만든 $10 \mathrm{mg} / \mathrm{ml} \mathrm{5 \%}$ PG-Platycodin D를 격일 단위로 처리하여 주었다. $\mathrm{DNCB}$ 군 과 $\mathrm{PD} 5 \%+\mathrm{DNCB}$ 군에서의 접촉피부염 유발 여부는 직접 육

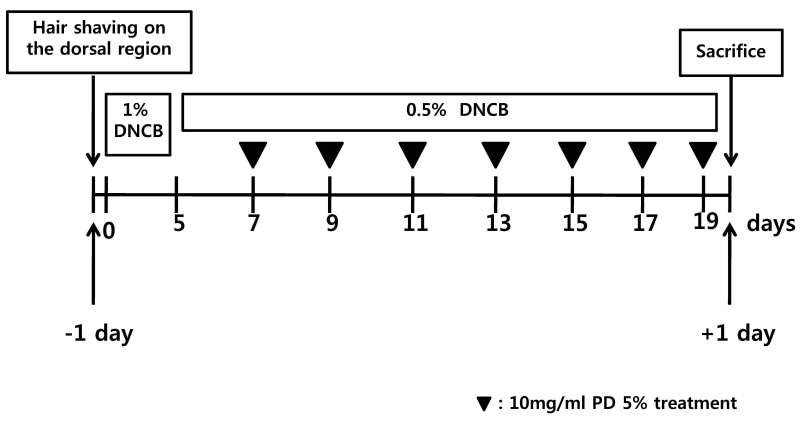

Fig. 1. Experimental Design.
안으로 확인할 수 있었다.

\section{Scratching behavior 측정}

Scratching behavior 측정 실험을 위하여 각각의 Mice는 개별적으로 깨끗한 polycarbonate cage에서 생활하게 하였으 며, $\mathrm{DNCB}$ 에 의해서 sensitization된 mice 및 $10 \mathrm{mg} / \mathrm{ml}$ 의 $5 \%$ PG-Platycodin D를 처리한 mice의 행동 양식을 2 주 동안 60 분 씩 격일 단위로 video camera를 이용하여 동영상 촬영 하였다. Scraching behavior는 등쪽 부위를 물어뜯거나 뒷발로 긁는 등의 행동양식을 횟수로서 측정하였다.

\section{Skin severity score 측정}

Skin severity 측정 평가 방법은 아토피성 피부염에서 일반 적으로 사용되는 임상적 육안 평가법으로서 아토피 피부염의 심각성 정도를 홍반(Erythma), 가려움과 건조피부(Pruritus \& Dry skin), 부종과 혈종(Edema \& Excoriation), 짓무름 (Erosion), 태선화(Lichenification)와 같은 5가지 항목을 각각 평가한 점수의 총 합으로 나타낸다. 각각의 항목에 대하여 증 상 없음(0점), 증상 약함(1점), 보통(2점), 심함(3점)으로 채점한 후, 5 항목의 점수를 합산함으로써 최소 0 점에서 최고 15 점 사 이의 평가점수를 부여하였다[15].

\section{피부조직 병리검사}

실험종료 후에, 등쪽 부위의 피부를 적출하여 $4 \%$ paraformaldehyde에서 4 시간 동안 고정하고, $30 \%$ sucrose 용액 에서 안정화 시켜주기 위해 overnight하였다. 그 조직을 Tissue-Tek O.C.T Compound (SAKURA, USA)로 포매하였 다. 그 조직은 부종 여부를 확인할 수 있도록 haematoxylin-eosin 염색법을 이용하여 조직 염색을 하였으며, 광학 현미경상에서 40 배의 배율로 피부의 전반적인 상태를 관찰 하였다.

\section{결과 및 고찰}

\section{PG-Platycodin D가 DNCB에 의해 유도된 접촉피부염에} 미치는 피부 개선 효과

본 연구에서는 PG-Platycodin D의 알레르기성 아토피 피 부염에 대한 회복능을 조사하기 위하여 normal군과 $\mathrm{DNCB}$ 로 알레르기 접촉피부염을 유발시킨 $\mathrm{DNCB}$ 군 및 $\mathrm{DNCB}$ 군에 PG-Platycodin D를 도포한 실험군으로 나누어 실험을 실시하 였다. 육안적 관찰에서 $\mathrm{DNCB}$ 군은 등 부위에 피부 반점, 홍반, 피부 건조, 부종 및 출혈 등이 심하게 나타났다. 이러한 상태의 mice에 PG-Platycodin D를 3회 도포하면 환부의 피부염이 어 느정도 회복되는 양상을 볼 수 있었다. 또한 7 회 도포 시에는 거의 정상 피부 상태로 회복되었다(Fig. 2). 

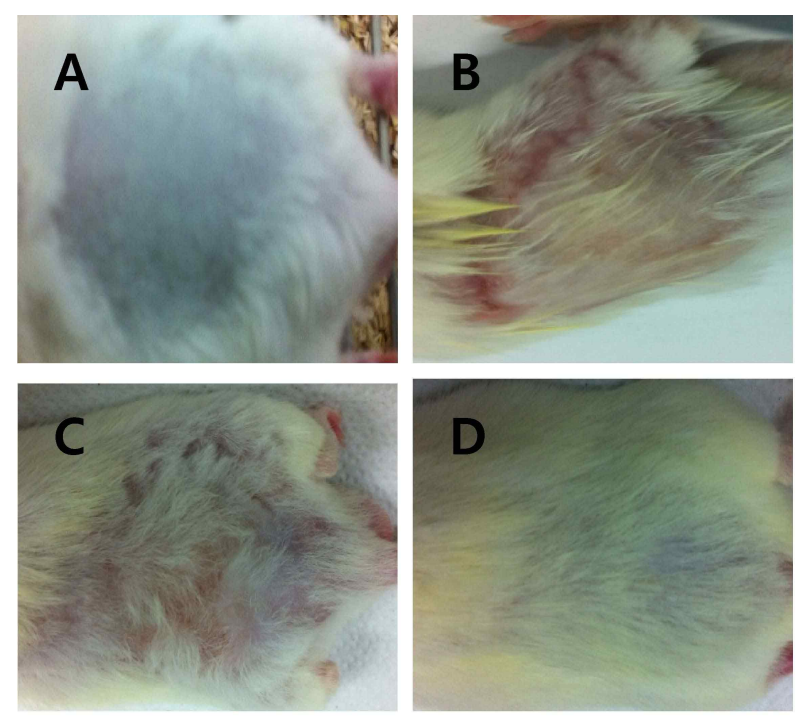

Fig. 2. Effect of PG-Platycodin D on DNCB-induced atopic dermatitis-like model in ICR mice. (A) untreated groups, (B) groups treated with DNCB alone, $(\mathrm{C})$ groups treated with PG-Platycodin D $(10 \mathrm{mg} / \mathrm{ml})$ three times after the treatment of DNCB, (D) groups treated with PG-Platycodin D $(10 \mathrm{mg} / \mathrm{ml})$ seven times after the treatment of DNCB.

PG-Platycodin D가 DNCB에 의해 유도된 알레르기성 아토피 피부염에 미치는 조직학적 영향

조직학적으로 $\mathrm{DNCB}$ 군의 피부 조직은 피부표면의 출형과 표피부의 비대화가 두드러져 normal군의 표피부에 비해 2-3 배 이상 두꺼워진 형태로 나타나고 있다. 그러나 PGPlatycodin $\mathrm{D}$ 를 도포한 실험군에서는 표피층의 두께가 점차 normal군과 같은 두께로 회복되고 있는 것으로 관찰되었다 (Fig. 3). 알레르기성 아토피 피부염의 피부조직에서는 탈 과립 화가 일어나는 비만세포와 호산구가 조직에 침윤하며 표피의 과각질화가 일어나게 된다. 알레르기성 아토피 피부염이 유발
되면 피부 표면의 수분 증발이 증가되어서 항원의 침투가 용 이해지므로 피부의 과민반응이 더욱 심화되어 세라마이드에 결합하는 매트릭스 구조 단백질에 의해 형성되는 피부장벽을 약화시키므로 감염과 염증에 대한 감수성이 높아지게 되는 것으로 알려져 있다[16,19,21]. 따라서 면역 반응에 의한 피부 염의 치료를 위해서는 자극을 일으키는 항원을 제거하는 것이 중요하다. 하지만 특이적 항원을 알 수 없는 경우도 많기 때문 에 일반적으로 항생제와 국소적으로 스테로이드 제제를 사용 하여 치료하는 경우가 보통이다. 이러한 치료는 장기간 지속 될 경우 안정성에 문제가 발생한다. 본 연구에서 PGPlatycodin D를 알레르기성 아토피 피부염이 유발된 피부에 7회 도포할 경우 효과적인 피부 회복능을 나타내고 있기 때문 에 알레르기성 아토피 피부염에 대한 제제로서 가능성을 제시 해주고 있다.

Skin severity와 scratching behavior에 있어서 PGPlatycodin D의 효과

알레르기성 아토피 피부염이 발생하였을 때 나타나는 표피 상의 증상으로서 극심한 가려움증과 더불어 홍반이나 건조한 피부, 짓무르는 현상 그리고 혈종이나 부종의 형성을 들 수 있다[21,23]. 따라서 이러한 알레르기성 아토피 피부염의 심각 성 정도를 홍반(Erythma), 가려움과 건조피부(Pruritus \& Dry skin), 부종과 혈종(Edema \& Excoriation), 짓무름(Erosion), 태선화(Lichenification)와 같은 5가지 항목을 각각 평가한 점 수의 총합으로 나타내었을 때, 2주 동안 PG-Platycodin D를 처리하였을 경우, 4 회차 도포 이후부터 $\mathrm{DNCB}$ 군에 비해서 점 차 그 score가 감소되는 것을 확인할 수 있었다(Fig. 4). 이를 통하여 PG-Platycodin D의 지속적인 처리가 관능적으로도 알 러지성 아토피 피부염의 개선에 영향을 미친다는 점을 알 수 있었다.

또한 $\mathrm{DNCB}$ 에 의해서 sensitization된 mice 및 $10 \mathrm{mg} / \mathrm{ml}$ 의 $5 \%$ PG-Platycodin D를 처리한 mice의 행동 양식을 2주 동안
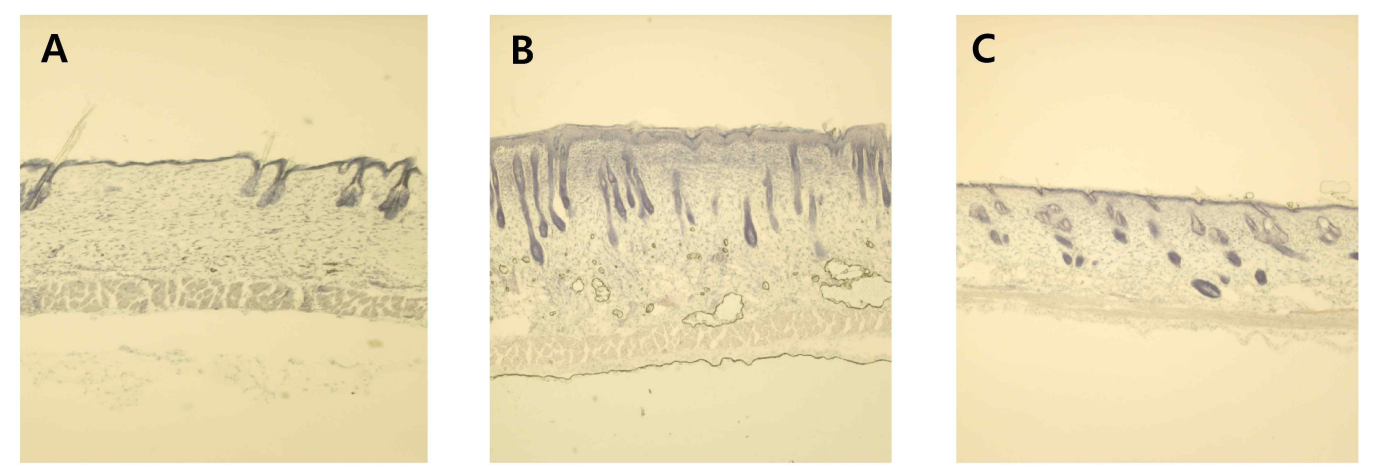

Fig. 3. Effect of PG-Platycodin D on DNCB-induced atopic dermatitis-like model in ICR mice by tissue section and H\&E staining. Dorsal skins were removed and fixed with $4 \%$ paraformaldehyde solution. To stabilize skins, 30\% sucrose solution was used overnight condition. (A) untreated groups, (B) groups treated with DNCB alone, (C) groups treated with PG-Platycodin $\mathrm{D}(10 \mathrm{mg} / \mathrm{ml})$ seven times after the treatment of DNCB. 


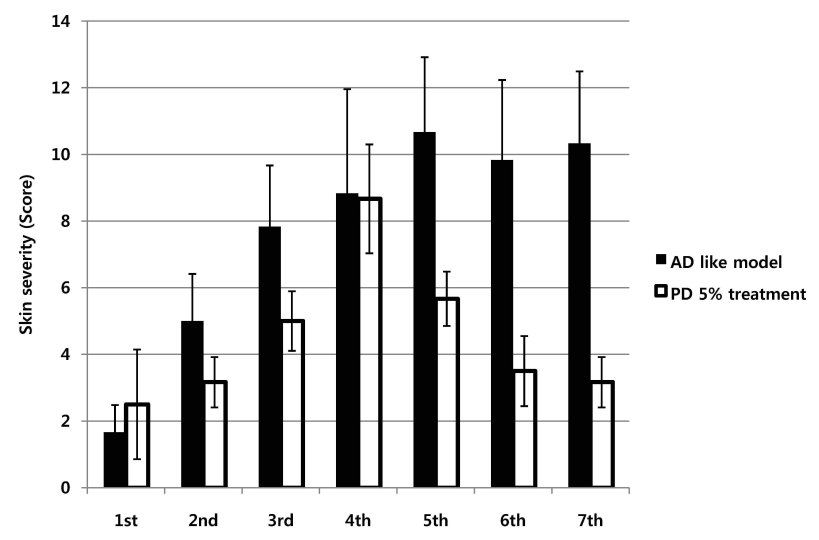

Fig. 4. Effect of PG-Platycodin D on Skin severity score. The skin severity of mice was assessed macroscopically in a blinded fashion as mentioned in materials and methods. The evaluated symptoms consisting of (1) Erythma, (2) Pruritus \& Dry skin, (3) Edema \& Excoriation, (4) Erosion, (5) Lichenification were scored as folows: none $=0$; mild $=1$; moderate $=2$; severe $=3$. The sum of the scores for each evaluated symptom (maximum score: 15) was considered as the skin severity score. The skin severity was evaluated every time after PG-Platycodin D treatment.

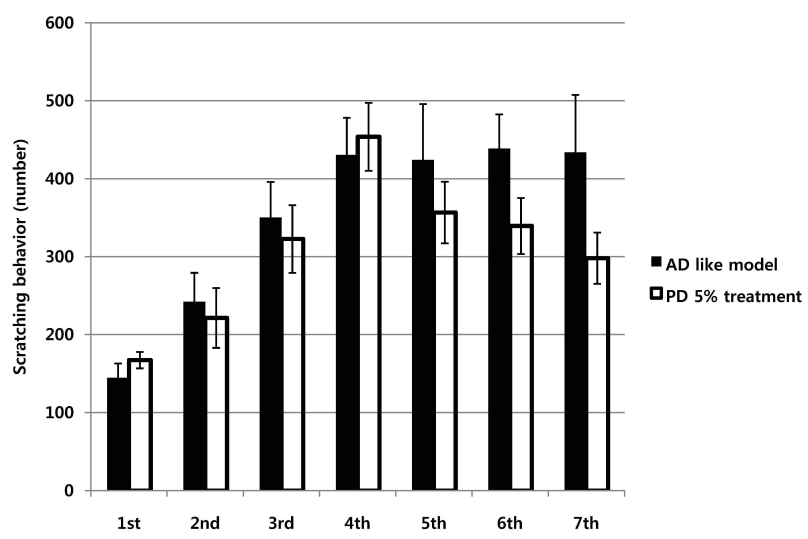

Fig. 5. Effect of PG-Platycodin D on scratching behavior. The scratching behavior of each mouse was videotaped for 60 minutes after sensitization. Scratching and biting of the dorsal skin with hind paws was observed during play back. Licking of the belly and dorsal skin during grooming was disregarded.

60 분씩 격일 단위로 video camera를 이용하여 동영상 촬영하 였다. 등쪽 부위를 물어뜯거나 뒷발로 긁는 등의 행동양식인 scratching behavior를 횟수로서 측정하였을 때, Scratching behavior 역시 PG-Platycodin D 도포 4회차 이후부터 등쪽 부위를 긁는 횟수가 점진적으로 감소하는 양상을 나타냈다 (Fig. 5). 따라서 PG-Platycodin D가 DNCB로 인하여 발생된 알레르기성 아토피 피부염을 효과적으로 억제해주는 기능을
할 것으로 생각된다.

\section{감사의 글}

본 연구를 위해 PG-Platycodin D를 제공해 주신 (주)비엔씨 바이오팜 김종우 대표께 감사의 말씀을 전합니다. 본 연구는 농림수산식품부 농림바이오기술산업화지원사업(810007-032-SB220)에 의해 이루어진 것임.

\section{References}

1. Chio, K. U. and Paek, D. M. 1995. Asthma and air pollution in Korea. Kor. J. Epidemiol. 17, 64-75.

2. Chung, J. H., Shin, P. G. and Cho, S. H. 1997. Chemical compositions of platycodon grandiflorus. J. Kor. Agric. Chem Biotech 40, 148-151.

3. Chung, J. H., Shin, P. G. and Cho, S. H. 1997. Pharmaceutical substances of platycodon grandiflorus. J. Kor. Agric. Chem Biotech 40, 152-156.

4. Dal-Pizzol, F., Klamt, F., Vianna, M., Schroder, N., Quevedo, J., Benfato, M. S., Moreira, J. C. and Walz, R. 2000. Lipid peroxidation in hippocampus early and late after status epilecticus induced by pilocarpine or kainic acid in Wistar rats. Neurosci. Lett. 291, 179-182.

5. Gombert, M., Dieu-Nosjean, M. C., Winterberg, F., Bunemann, E., Kubitza, R.C., Da, Cunha, L., Haahtela, A., Lehtimaki, S., Muller, A., Rieker, J., Meller, S., Pivarcsi, A., Koreck, A., Fridman, W. H., Zentgraf, H. W., Pavenstadt, H., Amara, A., Caux, C., Kemeny, L., Alenius, H., Lauerma, A., Ruzicka, T., Zlotnik, A. and Homey, B. 2005. CCL1-CCR8 interactions: an axis mediating the recruitment of $\mathrm{T}$ cells and Langerhans-type dendritic cells to sites of atopic skin inflammation. J. Immunol. 174, 5082-5091.

6. Ishizaka, K. 1984. Regulation of IgE synthesis. Ann. Rev. Immunol. 2, 159-182.

7. Kaburagi, Y., Shimada, Y., Nagaoka, T., Hasegawa, M., Takehara, K. and Sato, S. 2001. Enhanced production of CC-chemokines (RANTES, MCP-1, MIP-1alpha, MIP-1beta, and eotaxin) in patients with atopic dermatitis. Arch Dermatol. Res. 293, 350-355.

8. Kang, S. Y., Hue, S. H. and Kim, S. I. 1978. Immunologic aspects of hypersensitivity disease in Korea. Seoul Medicine $19,12$.

9. Kim, C. H. and Chung, M. H. 1975. Pharmaceutical studies on Codonopsis lanceolate. Kor. J. Pharmacog. 6, 43-47.

10. Kim, H. D. and Lee, J. W. 1972. Analysis of components of saponin from Ginseng, platycodon and Japanese touchwood. Kor. J. Pharmacog. 3, 51-54.

11. Kim, M. H., Kim, M. C., Park, J. S., Kim, J. W. and Lee, J. O. 2001. The antioxidative effects of the water-soluble extracts of plants used as tea materials. Kor. J. Food Sci. Technd. 33, 12.

12. Kim, S. Y., Kim, H. S. and Chung, S. Y. 1993. Effect of the 
feeding Platycodon grandiflotum and codonopsis lanceolata on the lipid components of serum and liver in rats. J. Kor. Soc. Food Nutr. 22, 524-530.

13. Klamt, F., Dal-Pizzol, F., Frota, M. L., Walz, R., Andrades, M. E., Silva, E. G., Brentani, R., Izquierdo, I. and Moreira, J. C. 2001. Imbalance of antioxidant defence in mice lacking cellular prion protein. Free Radic. Biol. Med 30, 1137-1144.

14. Lee, E. B. 1974. Phamacological studies on platycodi radix. Kor. J. Pharmacog. 5, 49-56.

15. Leung, D. Y. M. 1995. Atopic dermatitis: the skin as a window into the pathogenesis of chronic allergic disease. $J$. Allergy Clin. Immunol. 96, 312-319.

16. Matsuda, H., Watanabe, N., Geba, G. P., Sperl, J., Tsudzuki, M., Hiroi, J., Matsumoto, M., Ushio, H., Saito, S., Askenase, P. W. and Ra, C. 1997. Development of atopic dermatitis-like skin lesion with IgE hyperproduction in NC/Nga mice. Int. Immunol. 9, 461-466.

17. Neis, M. M., Peters, B., Dreuw, A., Wenzel, J., Bieber, T., Mauch, C., Krieg, T., Stanzel, S., Heinrich, P. C., Merk, H. F., Bosio, A., Baron, J. M. and Hermanns, H. M. 2006. Enhanced expression levels of IL-31 correlate with IL-4 and IL-13 in atopic and allergic contact dermatitis. J. Allergy Clin. Immunol. 118, 930-937.
18. Park, U. Y., Chang, D. S. and Cho, H. R. 1992. Screening of antimicrobial activity for medicinal herb extracts. J. Kor. Soc. Food Nutr. 21, 91-96.

19. Sator, P. G., Schmidt, J. B. and Honigsmann, H. 2003. Comparison of epidermal hydration and skin surface lipids in healthy individuals and in patients with atopic dermatitis. J. Am Acad Dermatol. 48, 352-358.

20. Tasaka, K. 1986. Antiallergic drug. Drugs Today 22, 101.

21. Vestergaard, C., Yoneyama, H., Murai, M., Nakamura, K., Tamaki, K., Terashima, Y., Imai, T., Yoshie, O., Irimura, T., Mizutani, H. and Matsushima, K. 1999. Overproduction of Th2-specific chemokines in NC/Nga mice exhibiting atopic dermatitis like lesions. J. Clin. Invest. 104, 1097-1105.

22. Wierenga, E. A., Snoek, M., Jansen, H. M., Bos, J. D., van, Lier, R. A. and Kapsenberg, M. L. 1991. Human atopen-specific types 1 and $2 \mathrm{~T}$ helper cell clones. J. Immunol. 147, 2942-2949.

23. Yamamoto, M., Haruna, T., Yasui, K., Takahashi, H., Iduhara, M., Takaki, S., Deguchi, M. and Arimura, A. 2007. A novel atopic dermatitis model induced by topical application with dermatophagoides farinae extract in $\mathrm{NC} / \mathrm{Nga}$ mice. Allergol. Int. 56, 139-148.

\section{초록 : Platycodin D를 포함하는 도라지 추출물이 DNCB 유도 알레르기성 아토피 피부염에 미치는 영향 박세진 ${ }^{1} \cdot$ 김윤석 $^{2} \cdot$ 김택중 $^{1}{ }^{*}$ \\ ( ${ }^{1}$ 연세대학교 과학기술대학 생명과학기술학부, ${ }^{2}$ 연세대학교 보건과학대학 임상병리학과)}

알레르기성 아토피 피부염은 면역적 반응을 포함하는 복잡한 원인을 가진 염증성 질환이다. 본 연구는 ICR mice의 등쪽 부위에 반복적인 DNCB 도포를 통해 유발시킨 알레르기성 아토피 피부염에 있어서 PG-Platycodin $\mathrm{D}$ 의 효능에 대해 연구하였다. PG-Platycodin D의 효능은 scratching behavior, skin severity score, 그리고 조직병 리학적 관찰을 통해서 확인하였다. PG-Platycodin D가 scratching behavior, skin severity score 수준을 감소시킴 을 확인할 수 있었다. 또한, 조직병리학적 관찰에 의해 PG-Platycodin D군에서 피부의 부종이 효과적으로 억제됨 을 알 수 있었다. 이러한 결과로부터 알레르기성 아토피 피부염에 있어서 Platycodin D가 포함된 도라지 추출물 이 유용한 천연 원료 물질로서 가능성을 가짐을 확인하였다. 